\title{
High Power Interleaved Boost Converter for Photovoltaic Applications
}

\author{
Ahmed A. Hafez',2, A. Y. Hatata1,3, M. I. Alsubaihi' ${ }^{1}$, R. M. Alotaibi' ${ }^{1}$, F. T. Alqahtani ${ }^{1}$, S. 0. Alotaibi', \\ A. M. Alhusayni' ${ }^{1}$ M. D. Alharbi ${ }^{1}$ \\ ${ }^{1}$ Electrical Engineering Department, College of Engineering, Shaqra University, Shaqra, KSA \\ ${ }^{2}$ Electrical Engineering Department, Faculty of Engineering, Assiut University, Assiut, Egypt \\ ${ }^{3}$ Electrical Engineering Department, Faculty of Engineering, Mansoura University, Mansoura, Egypt \\ Email: aabdelhafez@su.edu.sa
}

How to cite this paper: Hafez, A.A., Hatata, A.Y., Alsubaihi, M.I., Alotaibi, R.M., Alqahtani, F.T., Alotaibi, S.O., Alhusayni, A.M. and Alharbi, M.D. (2018) High Power Interleaved Boost Converter for Photovoltaic Applications. Journal of Power and Energy Engineering, 6, 1-17.

https://doi.org/10.4236/jpee.2018.65001

Received: April 1, 2018

Accepted: May 25, 2018

Published: May 28, 2018

Copyright $\odot 2018$ by authors and Scientific Research Publishing Inc. This work is licensed under the Creative Commons Attribution International License (CC BY 4.0).

http://creativecommons.org/licenses/by/4.0/

\begin{abstract}
Interfacing DC sources to load/power grid requires DC converters that produce minimum level of current ripples. This is to limit the losses and hence increase the life span of these sources. This article proposes a simple interleaved boost converter that interfaces PhotoVoltaic (PV) module into a common DC-link. The article also addresses the faulty mode operation of the proposed circuit while advising the appropriate remedy actions. A MATLAB and Simulink dynamic platform are used to simulate the transient performance of the proposed converter. The results revealed the effectiveness and the viability of the proposed converter in reducing the ripples in the PV current without employing bulky input inductors or increasing the switching frequency.
\end{abstract}

\section{Keywords}

Low Ripples, PV, Interleaved, Boost, Faulty, Remedy

\section{Introduction}

PV industry gains more intention recently, due to the salient advantages of PV modules as size variability, environmental compatibility and modularity. PV in general requires mechanical and electronic tracking for producing maximum output power at different levels of solar irradiance and temperature. Mechanical tracking could be efficient large-scale PV circuits as in utility scale PV installations. However, in residential and small-scale PV arrangements, usually mechanical tracking is ignored. This is to optimize the complexity and implementation costs. However, electronic tracking is mandatory for all scales of PV instal- 
lations [1].

Tracking of Maximum Power Point (MPP) usually is realized via a DC-DC converter; the control methodology is to increment/decrement PV voltage/current such that MPP is realized. In other approaches, PV voltage/current is forced to follow a predetermined reference. This reference is extracted from actual PV voltage and current [1] [2].

Basic DC-DC boost converter is the preferred for PV applications. This is due to topology of this converter. The inductor in the input side reduces the ripple in the current drawn from PV and hence its losses. Moreover, the diode in the basic cell protects the PV module from reverse current. However, for reduced ripple level in the PV current, a volumetric inductor has to be used [2] [3] [4]. This inductor impacts the weight and efficiency. Alternative solution is the application of interleaved boost converter.

Interleaved boost DC-DC converter consists of two cells of basic converter operating parallel. It is able to reduce the ripples in PV current without requirements of sizable inductor or high switching frequency. This is accomplished via introducing phase shift between the switching signals of the switches in the parallel cells. Moreover, the interleaved boost converter reduces efficiently the Electromagnetic Interference (EMI). The application of non-isolated interleaved boost converter was investigated in the literature for PV field [5] [6] [7] [8]. In general, a little is reported regarding the limitations of the interleaved boost converter.

The limitations of the interleaved boost converter are highlighted in this research, while conditions for ripple-free input current operation are identified [5] [6] [7] [8].

Different variety of MPP Tracking (MPPT) algorithms are reported in the literature [9] [10] [11] [12] [13]. These methods vary in complexity, topology suitability and tracking precision. MPPT approaches that involve current tracking are applicable for boost converter. Fractional short-circuit MPPT is simple and it is the most suitable for boost topology. However, it tracking precision is slightly lower than other methods as Perturbation \& Observation ( $P$ \& O) and Incremental Conductance Controller (ICC). ICC has better performance than P \& O and fractional short-circuit current, due to response speed of ICC. ICC has the advantages of wide applicability, as it is easily adopted in any DC-DC converter topology [9] [10] [11] [12] [13].

The reliability of power electronic components decreases with aging; therefore, there is considerable probability of faulty operation of interleaved boost converter. Less is reported in the literature about faulty mode of interleaved boost converter in PV applications. This results in decreasing the harvest power under such conditions as there is no comprehensive analysis or valuable remedy strategy [14].

Elaborate remedy strategies are advised for different faults in the operation of interleaved boost converter driving PV module, which are not widely reported 
[14]. This confirms the originality of this article.

This article analyzes comprehensively the operation of interleaved DC-DC boost converter for PV applications. The limitations on the output voltage of the converter are derived. An annotative implementation scheme for the modulation strategy ensuring equal value of switches' duty cycles is proposed. The article directs more emphasis on the faulty mode of the proposed converter operation. Different fault scenarios are investigated while advising the appropriate remedy strategy. This article has the following contributions:

1) Defining the upper limit of the duty cycle and hence output voltage for interleaved boost converter.

2) Proposing a simple modulation strategy ensuring equal values for the switches' duty cycles.

3) Investigating the operation of interleaved boost converter while a switch develops short/open circuit fault and advising the appropriate remedy scheme.

4) Proposing intelligent remedy scenario while the interleaved boost converter operating with open diode fault.

\section{Interleaved Boost Converter and PV Module}

The system under concern is composed of PV generator, interleaved boost converter and DC-link, as shown in Figure 1. The input DC capacitor is embedded to protect the PV generator and limit the losses, which results in increases lifespan of the PV module. The interleaved boost converter is chosen to interface PV module into common DC bus due to:

1) Interleaved boost converter has lower ripple level in the PV output current than the basic boost cell, which reduces the losses in the PV module and hence lengths its lifespan.

2) The interleaved boost converter has inherent short-circuit protection.

3) The interleaved boost converter has the same output voltage boosting ability as the basic cell.

\subsection{PV Generator Model}

Different models are advised for stimulating PV cell, these models differ in accuracy and complexity. Moderate model is advised here, the PV cell is modeled

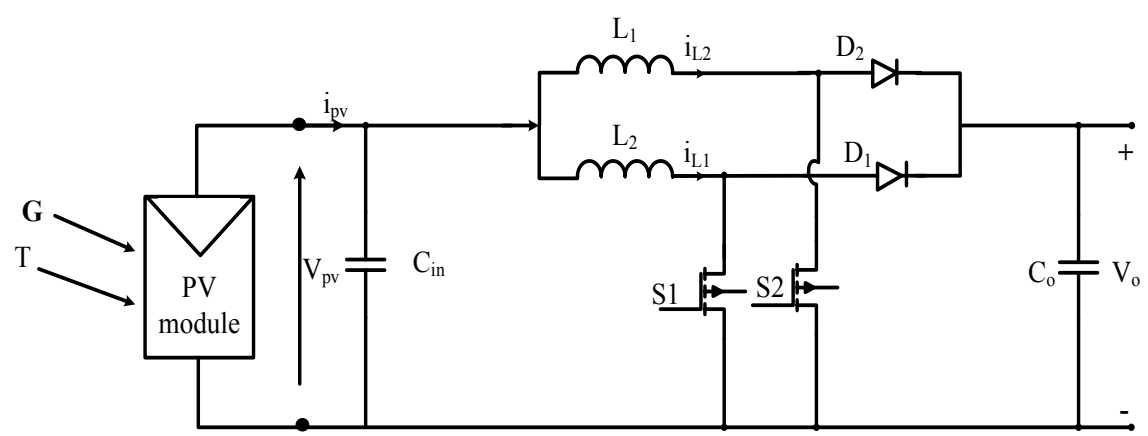

Figure 1. System under concern. 
as a solar irradiation and temperature dependent current source $I_{p h}$ in parallel with diode as shown in Figure 2. This combination is in series with a series resistance Rs [14]. This model of the PV has the advantages of accuracy, robustness and simplicity.

Basically, the PV cells are grouped in series to deliver a reasonable voltage/power, these structures as mentioned before are themed modules. The module has an equivalent circuit similar to that of the cell.

The relation between the terminal current $I$ and voltage $V$ of a PV module is expressed by [14],

$$
I=I_{p h}-I_{o}\left(\mathrm{e}^{\frac{V+I R_{s}}{V_{t h}}}-1\right)
$$

where $I_{o}, I_{p h}, I$ and $V$ are saturation current, photo current, current and voltage of the module. $V_{t h}=n N_{s} k T / q$ is thermal voltage of the module; $n, N_{s}, K, T$ and $q$ are ideality factor, number of cells in series, Boltz's man constant and electron charge respectively. The PV modules under concern are from Kyocera KC200GT type. The parameters of KC200GT module are given in Table 1 [14] [15] [16].

The value of series resistance $R_{s}$ calculated by iterative method in [14] is 0.221 $\Omega$.

The PV modules are grouped in series-parallel arrangement to form array, which is termed here as PV generator. Each PV generator is consisting of 30 Kyocera KC200GT modules. The relation between the PV array/generator terminal voltage $V_{p v}$ and current $I_{p v}$ could be expressed by a relation similarly to (1), however, it is more meaningful to express the PV array/generator current in

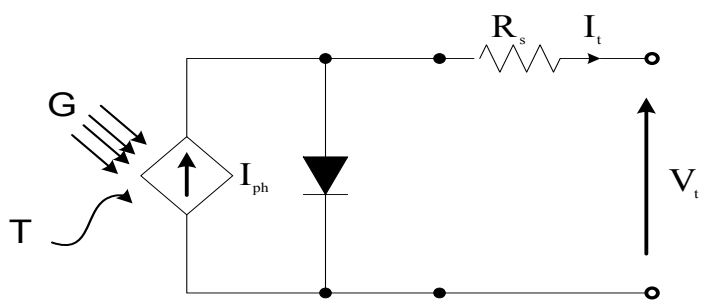

Figure 2. Equivalent circuit of PV cell/module.

Table 1. Parameters of KC200GT solar module at $25^{\circ} \mathrm{C}$ and $1000 \mathrm{~W} / \mathrm{m}^{2}$ [14] [15].

\begin{tabular}{cc} 
No. of cells & 54 \\
\hline Short circuit current & $8.21 \mathrm{~A}$ \\
Open circuit voltage & $32.9 \mathrm{~V}$ \\
Current at MPP & $7.61 \mathrm{~A}$ \\
Voltage at MPP & $26.3 \mathrm{~V}$ \\
Maximum power & $200.143 \mathrm{~W}$ \\
Voltage coefficient & $-0.1230 \mathrm{~V} / \mathrm{K}$ \\
Current coefficient & $0.0032 \mathrm{~A} / \mathrm{K}$
\end{tabular}


terms of the voltage $V_{p r}$ short-circuit current $I_{s c}$ and open-circuit voltage $V_{o c}$ of the module, as these data are commonly supplied by the manufacturers at standard test conditions [14].

$$
I_{p v}=M_{s s} I_{s c}\left(1-\exp \left(\frac{V_{p v}-N_{s s} V_{o c}+N_{s s} I_{p v} R_{s} / M_{s s}}{N_{s s} V_{t h}}\right)\right)
$$

where $M_{s s}$ and $N_{s s}$ are number of shunt and series connected modules respectively. The current $I_{p v}$ and the voltage $V_{p v}$ of the PV array/generator under concern calculated at $25^{\circ} \mathrm{C}$ and different radiation levels are given in Figure 3 and Figure 4 respectively.

Figure 3 and Figure 4 reveals that the voltage at maximum power is less dependent on the solar irradiation [14]. Moreover, the generator current/power varies almost linearly with the insolation. Figure 5 shows the relation between the short-circuit current and current maximum power point for different levels of solar irradiance.

Figure 5 shows that current at maximum power point nearly varies linearly with the short-circuit current. For the PV module under concern [9] [10] [11] [12], the relation between $I_{m p p}$ and $I_{s c}$ could be given by,

$$
I_{m p p}=k_{m p p s c} I_{s c}
$$

where $K_{m p p s c}$ is equal to 0.9286 , Figure 5 .

\subsection{Interleaved Boost Converter}

The interleaved boost converter as shown in Figure 1 is composed from two parallel boost cells, which operate in an interleaved mode. Therefore, there is

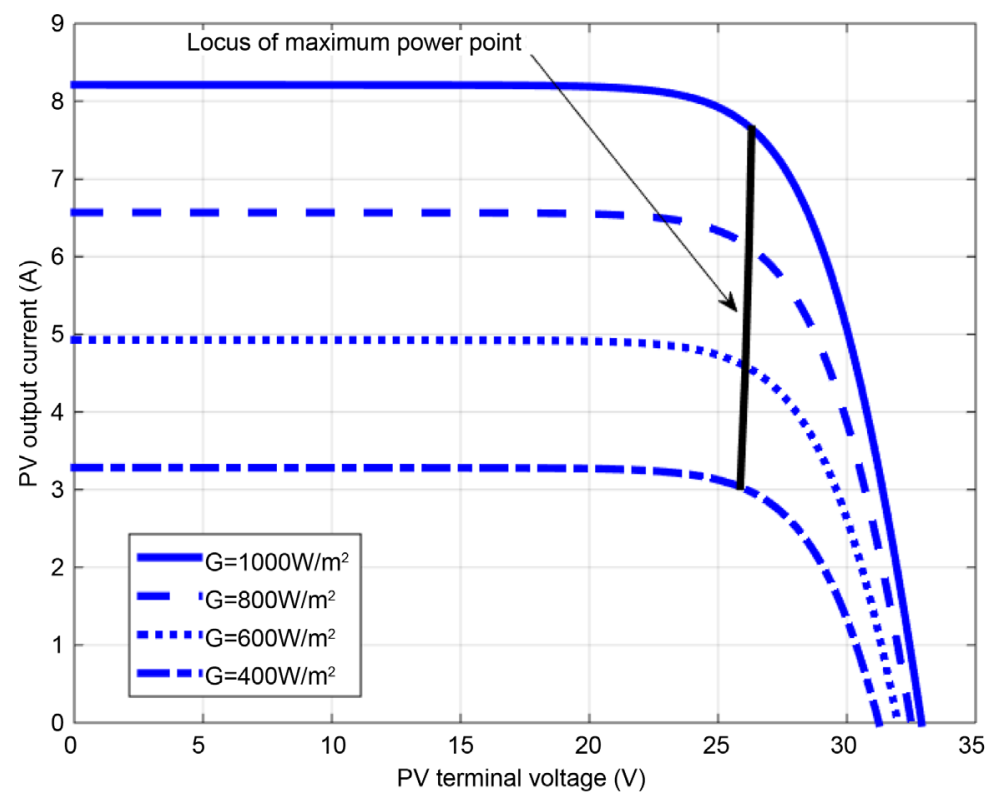

Figure 3. Current a PV generator versus terminal voltage for $25^{\circ} \mathrm{C}$ temperature and different levels of solar irradiance, locus of maximum power (black). 


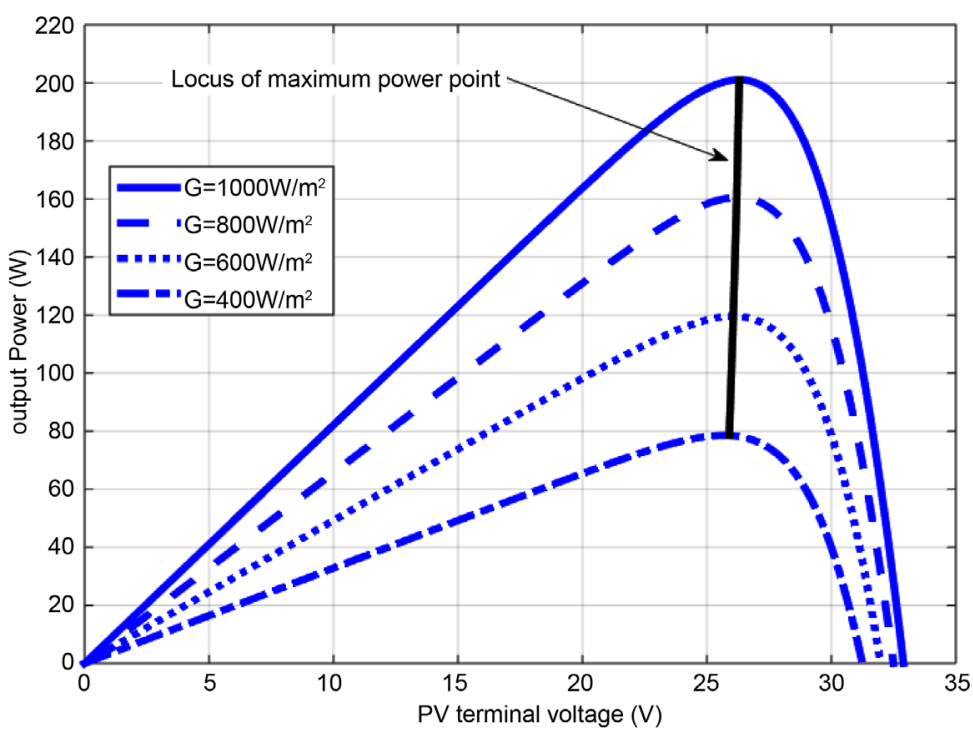

Figure 4. Power of a PV generator versus terminal voltage for $25^{\circ} \mathrm{C}$ temperature and different levels of solar irradiance, locus of maximum power (black).

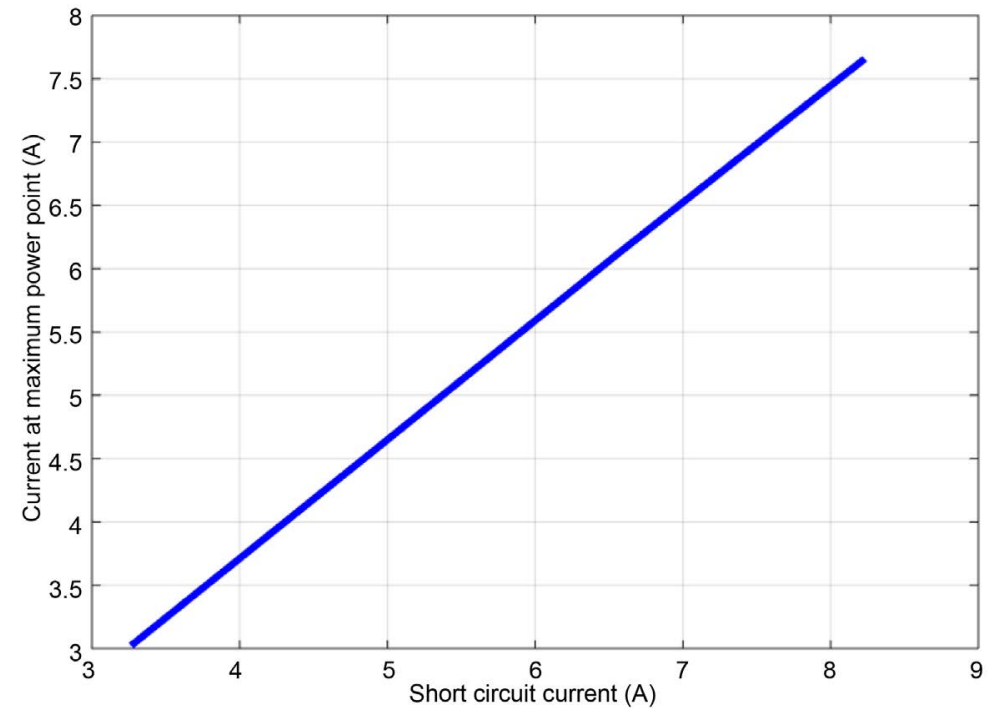

Figure 5. Short-circuit Current versus current at maximum power point for different solar insolation levels.

around $180^{\circ}$ phase shift between the ripples in the input current inductor of the two boost cells as shown in Figure 6. The input current, $\mathrm{I}_{\mathrm{L}}$, is the summation of currents $I_{L 1}$ and $I_{L 2}$. Therefore, the input current $\mathrm{I}_{\mathrm{L}}$ is nearly ripple free for $50 \%$ duty cycle.

Assume $\Delta I_{L 1}$ and $\Delta I_{L 2}$ are peak to peak ripples in the currents $I_{L 1}$ and $I_{L 2}$ respectively. Calculating $\Delta I_{L 1}$ and $\Delta I_{L 2}$ following the procedure in [15], they are given by,

$$
\Delta I_{L 1}=\frac{V_{s}}{L_{1}} D_{1} T_{s}
$$




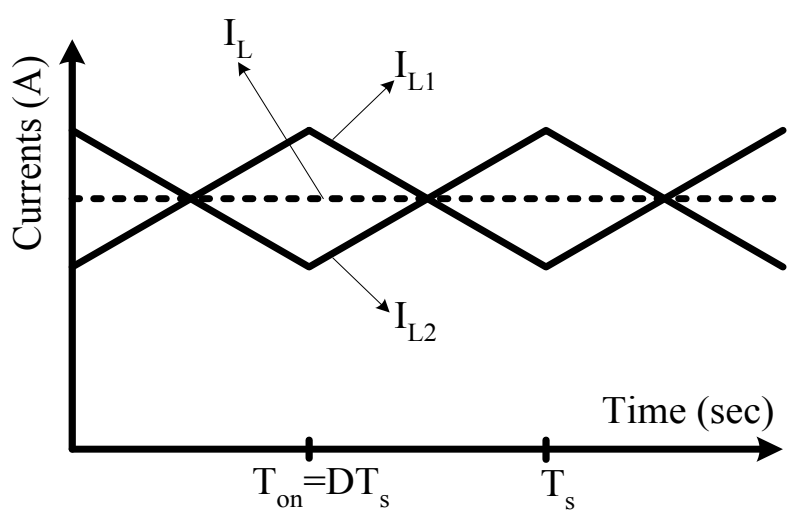

Figure 6. Current ripples of interleaved boost converter for $50 \%$ duty cycle.

$$
\Delta I_{L 2}=-\frac{V_{s}}{L_{2}} D_{2} T_{s}
$$

Assuming that $L_{1}$ and $L_{2}$ are equal, $L_{1}=L_{2}=L$. The ripples in the input current $I_{L}$ is given by,

$$
\Delta I_{L 1}+\Delta I_{L 2}=\frac{V_{s}}{L} T_{s}\left(D_{1}-D_{2}\right)
$$

Equation (6) shows that zero ripple in the input current IL could be realized if $D_{1}=D_{2}$. However, this condition places a limit on the maximum value of the duty cycles $D_{1}$ and $D_{2}$. As, the two cells operate in cascaded pattern; therefore, $D_{1}$ $+D_{2}=1.0$. Therefore, for zero ripple in the inductor current $D_{1}=D_{2}=D$, and the duty cycle of each boost cell is limited by,

$$
0<D \leq 0.5
$$

Equation (7) indicates that maximum value of a cell duty cycle is 0.5 ; this set the maximum output voltage of interleaved boost converter to twice input voltage. This considers a major deficiency in the interleaved boost converter. There is no limitation on the output voltage of basic boost converter as compared to the interleaved boost chopper.

\section{Proposed MPPT}

The slope of power-voltage curve of a PV generator, Figure 4, could be expressed by,

$$
\begin{aligned}
& \frac{\Delta I_{p v}}{\Delta V_{p v}}>-\frac{I_{p v}}{V_{p v}} \text {, left MPP } \\
& \frac{\Delta I_{p v}}{\Delta V_{p v}}=-\frac{I_{p v}}{V_{p v}} \text {, at MPP } \\
& \frac{\Delta I_{p v}}{\Delta V_{p v}}<-\frac{I_{p v}}{V_{p v}} \text {, right MPP }
\end{aligned}
$$

where $I_{P V}, V_{P V}$ and $P_{P V}$ are PV module current, voltage and power respectively.

The slope of power-voltage curve of a PV module, Figure 4, is positive on the 
left of MPP, negative on the right and zero at MPP. Thus, the relation between the incremental and instantaneous conductance is given by,

$$
E=\frac{\Delta I_{p v}}{\Delta V_{p v}}+\frac{I_{p v}}{V_{p v}}
$$

MPP is tracked by continuously comparing the incremental and instantaneous conductance and incrementing/decrementing the PV voltage/current until MPP is reached. This technique is reported in the literature under ICC [9].

An innovative implementation for ICC is proposed here under the theme of Modified Incremental Conduction Controller (MICC). According to (9), the sum of the incremental and instantaneous conductance is equal to zero at MPP; therefore, employing a sufficiently fast PI controller ensures that sum is settled at zero.

$$
E=\frac{\Delta I_{p v}}{\Delta V_{p v}}+\frac{I_{p v}}{V_{p v}}
$$

This article proposes an innovative approach to ensure equal duty cycle for the switches of the converter. This is the condition for zero ripple, which is extracted from (6). Sawtooth of a switch is inversion for the other switch as shown in Figure 7. Moreover, the PI output DC signal is limited to half of Sawtooth amplitude. This is to comply with (7). The proposed modulation strategy ensures equal value for the switches' duty cycles and not violating the $50 \%$ upper limit of the duty cycle. The parameters of interleaved boost converter are given in Table 2.

\section{Controller Tuning}

To tune the proposed PI controller, the large signal model of the system under

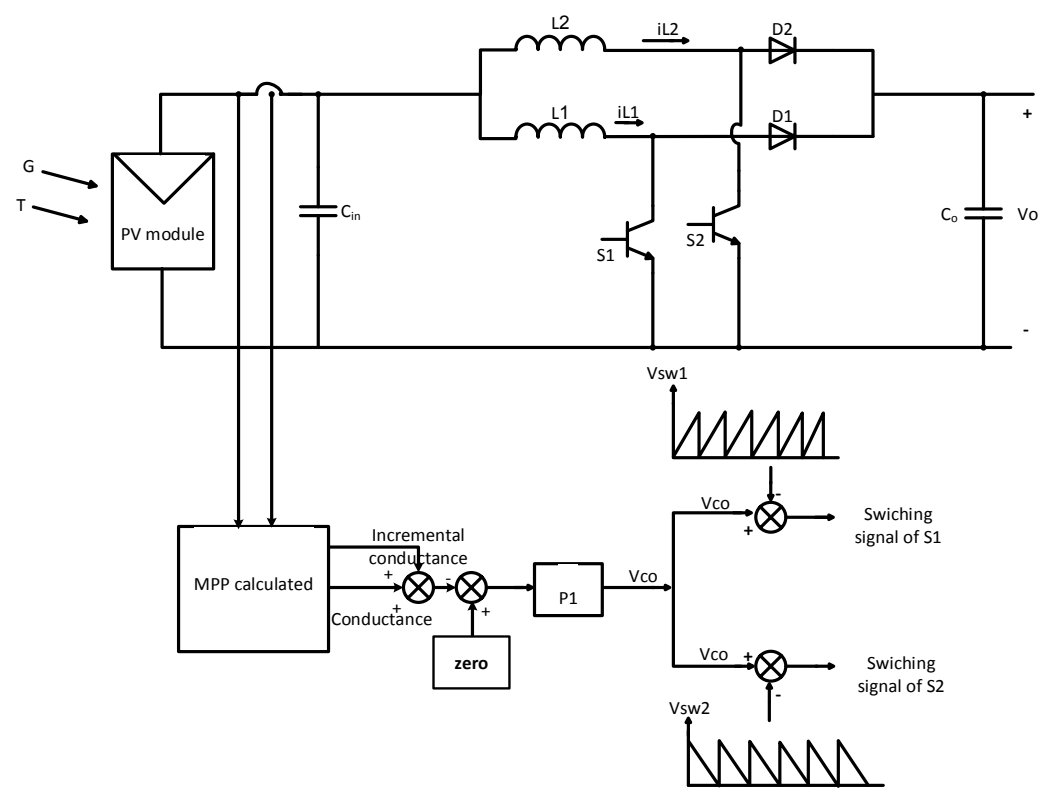

Figure 7. Boost converter and modulation strategy. 
Table 2. Parameters of interleaved boost converter.

$\begin{array}{cc}\text { Inductors } L_{1} & L_{1}=100 \mu \mathrm{H} \\ \text { Inductors } L_{2} & L_{2}=100 \mu \mathrm{H} \\ \text { Input capacitance } C_{i n} & C_{i n}=50 \mu \mathrm{F} \\ \text { Output capacitance } C_{o} & C_{o}=100 \mu \mathrm{F}\end{array}$

concern has to be obtained [15] [16]. The following assumption are considered:

1) The input/output capacitors $C_{i n}$ and $C_{o}$ are sufficiently large, so that the PV module output voltage $V_{p v}$ and output voltage $V_{o}$ are constant.

2) The converter input current is ripple free.

The dynamic performance model of the interleaved boost converter is similar to the basic boost topology. Averaging over a switching cycle, the dynamic performance of the interleaved boost chopper could be depicted by [17] [18],

$$
\begin{aligned}
L \frac{\mathrm{d} i_{L}}{\mathrm{~d} t} & =V_{p v}-V_{o}(1-D) \\
C_{o} \frac{\mathrm{d} V_{o}}{\mathrm{~d} t} & =-\frac{V_{o}}{R_{L}}+i_{L}(1-D)
\end{aligned}
$$

where $i_{L}, V_{o}, R_{L}$ and $C_{o}$ are respectively inductor current, output voltage, load resistance and output capacitance respectively. $D$ is the duty cycle.

Perturbing (11)-(12) and linearizing around a steady-state operating point and transforming into Laplace Transform [19].

$$
\begin{gathered}
s L I_{L}(s)=-V_{o}(s)\left(1-D_{o}\right)+D(s) V_{o s} \\
s C_{o} V_{o}(s)=\frac{-V_{o}(s)}{R_{L}}+I_{L}(s)\left(1-D_{o}\right)-I_{L a v} D(s)
\end{gathered}
$$

where $D_{o}, I_{L a v}$ and $V_{o s}$ are steady-state values of duty cycle, average inductor current and output voltage. Rearranging (13) and (14), solving for $V_{o}(s)$; then substituting $V_{o}(s)$ in terms of $I_{L}(s)$ and $D(s)$, the transfer function between inductor input current and duty cycle is given by,

$$
\frac{V_{o}(s)}{D(s)}=G_{v}(s)=\frac{-s \frac{L}{R_{L}\left(1-D_{o}\right)} V_{o s}+V_{o s}\left(1-D_{o}\right)}{\left(s^{2} C L+s \frac{L}{R_{L}}\right)+\left(1-D_{o}\right)^{2}}
$$

A PI controller with parameters given in Table 3 is used to force the operating point to track MPP irrespective to solar irradiance and temperature levels. The system and the open control transfer function transfer function are illustrated in Figure 8.

The open loop transfer function has two complex poles and one right hand zero. Therefore, the PI controller has to ensure the stability while achieving reasonable bandwidth. The proposed PI controller, Table 3, produces around $2.5 \times$ $10^{5} \mathrm{rad} / \mathrm{sec}$ bandwidth. This bandwidth is sufficient high such that the rapid 
Table 3. Parameters of PI controller.

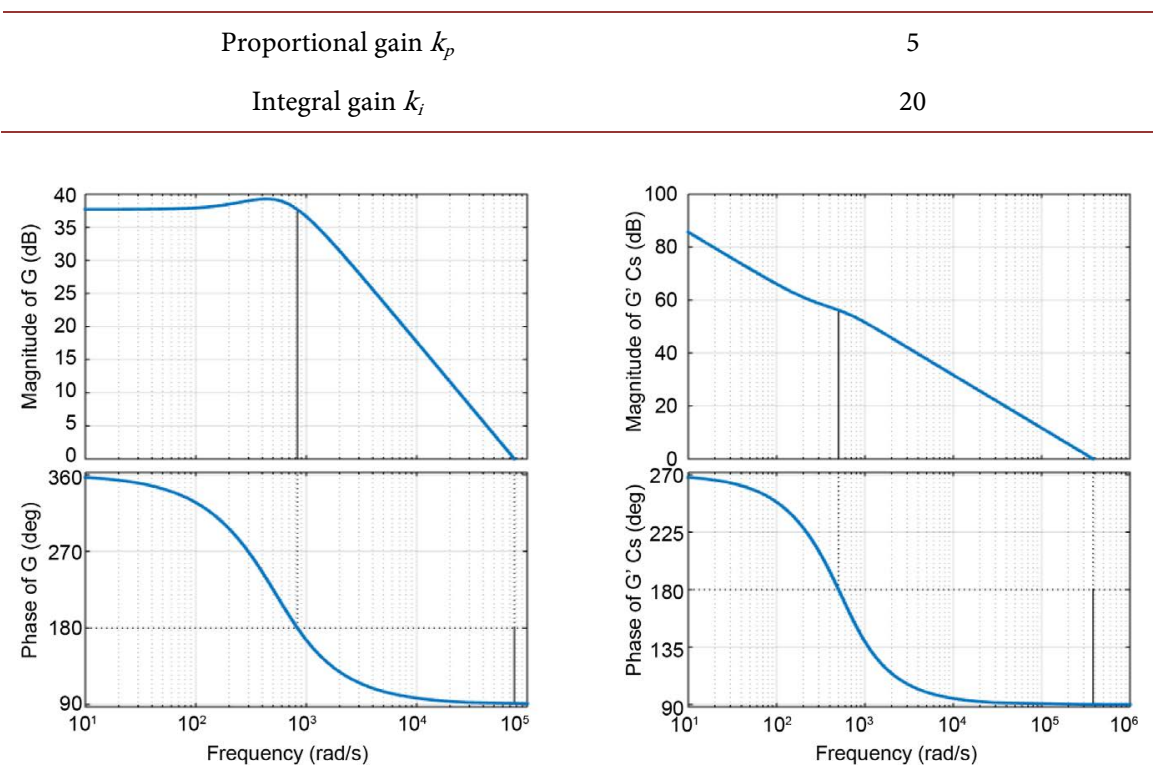

Figure 8. System transfer function (left) open control transfer function (right).

fluctuation in the solar irradiance are efficiently tracked. The proposed PI produce $52 \mathrm{~dB}$ and $89^{\circ}$ gain and phase margin.

\section{Results and Discussions}

MATLAB and its dynamic platform, Simulink, are used to stimulate the system under concern with the proposed control methods and MPPT technique. A solar irradiance that varies according to daytime is considered for validating the system under concern. This pattern of solar irradiance is shown in Figure 9. The PV output power, voltage and current are illustrated. The currents and the ripples in the inductors of the two cells also are given in Figures 9-11.

The ICC successfully forces the PV generator to operate at MPP at different solar irradiance, Figure 9. Figure 9 shows clearly the linear dependency between the solar irradiance and PV output power.

Figure 10 shows that $\mathrm{PV}$ terminal voltage is slightly solar irradiance dependent. The DC-link output voltage is not constant as the interleaved boost converter is controlled such that MPP is tracked at different solar irradiance irrespective to the output voltage.

Figure 12 shows that the PV input current is linearly proportionated with solar irradiance, Figure 9. The oscillations in the currents of the inductors may be due the interaction between the inductors and input/output capacitances. It is clear that the proposed cancellation technique is working as shown in bottom graph of Figure 11.

\section{Remedy Strategy}

Faulty mode of the interleaved boost under concern considers only the defects in 

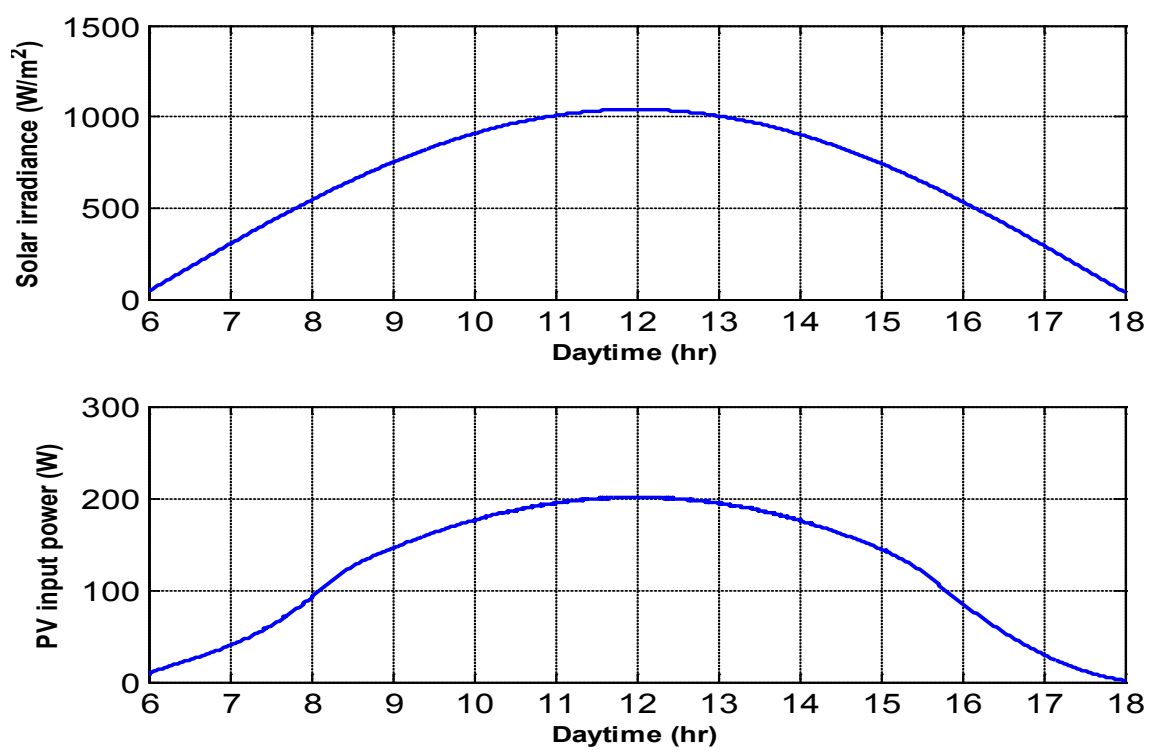

Figure 9. Solar irradiance over a daytime(top) and PV output power (bottom) for $25^{\circ} \mathrm{C}$.
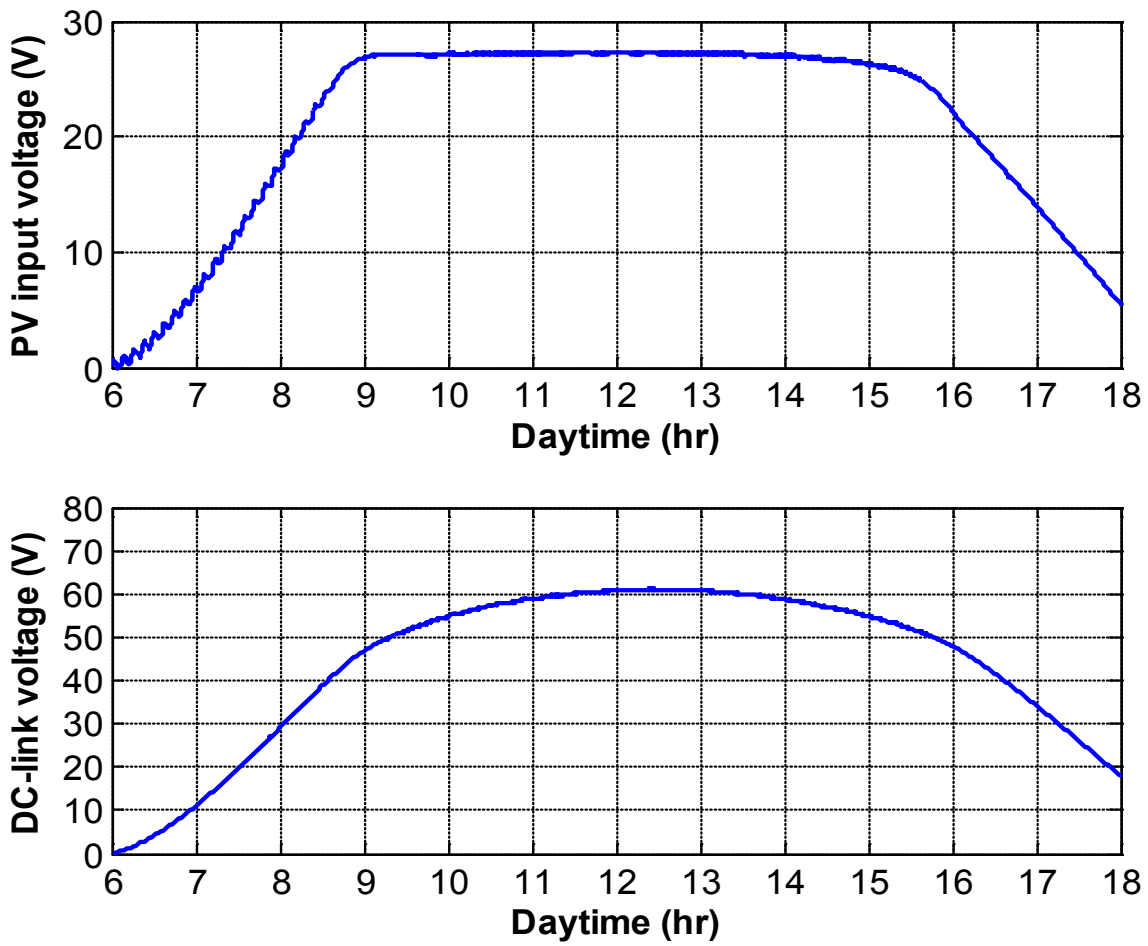

Figure 10. PV generator terminal voltage (top) and DC-link voltage (bottom) for varying solar irradiance and $25^{\circ} \mathrm{C}$.

power electronic elements. The failure of input/output capacitors is out of scope of this research. There are three scenarios under concern. They are:

1) Scenario\# 1 a switch open-circuit fault.

2) Scenario\#2 a switch short-circuit fault.

3) Scenario\#3 a diode open-circuit fault.

Appropriate remedy strategies are identified for each scenario. 

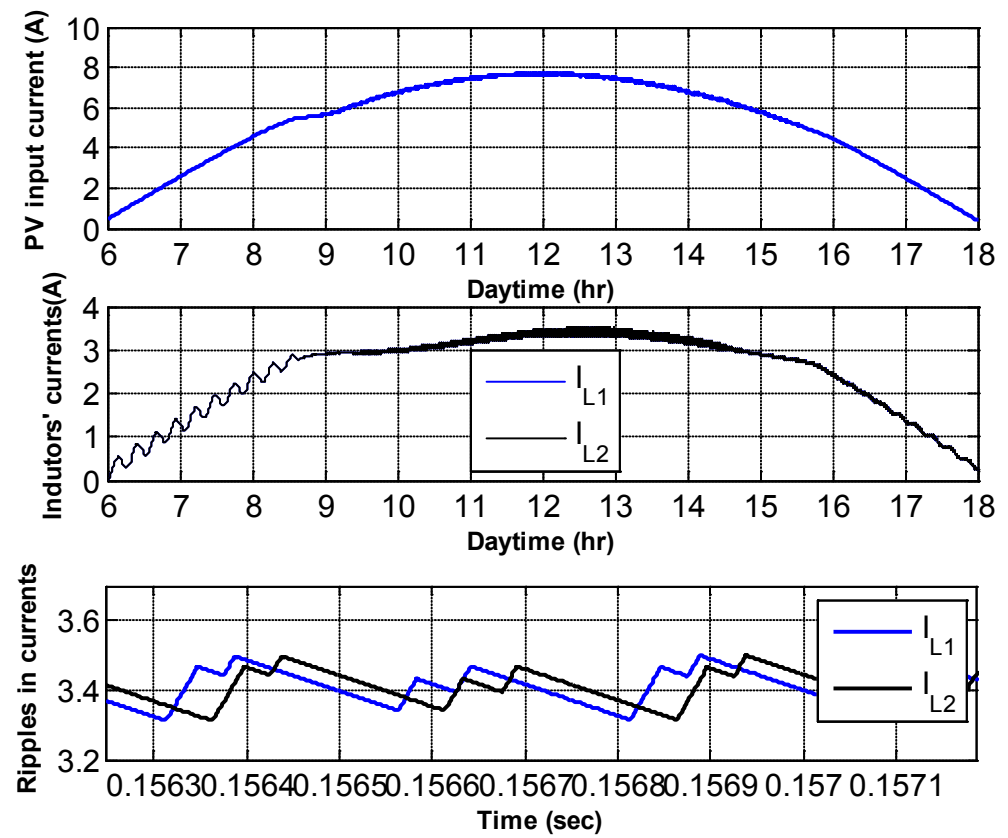

Figure 11. PV generator input current (top), inductors' currents (middle) and ripples in the currents (bottom) for varying solar irradiance and $25^{\circ} \mathrm{C}$.

\subsection{Scenario\#1 a Switch Open-Circuit Fault}

If a switch in a boost cell develops open-circuit fault, the current in this switch diminishes to zero. Moreover, the diode of this cell would be reveresbias, therefore the current in the inductor of the faulty cell drops to zero. However, as the interleaved boost converter consists of two cells. The other cell still operates and fulfills the load. This scenario is illustrated in Figure 12 and Figure 13, where the PV module input current, inductors' currents, PV output power and voltage are drawn. Here in this scenario, the solar irradiance is assumed constant at 1000 $\mathrm{W} / \mathrm{m}^{2}$ during the simulation time span.

Figure 12 shows that prior the fault the system was operating at MPP. Then, the system operation is diverted from MPP after the fault. Moreover, the ripple cancellation technique efficiently reduces ripple level in the PV input current.

Figure 13 shows that the system only experience around 4\% drop in the output power. The increase in the PV output voltage is due to diversion from MPP operation (Figure 13).

\subsection{Scenario\#2 a Switch Short-Circuit Fault}

Short-circuit switch fault is the severest, as the PV generated would operate at short-circuit operating point, where the output power is zero and the current is maximum. This scenario is illustrated in Figure 14, where the PV input current and DC-link voltage are drawn. Again, the solar irradiance is assumed constant at $1000 \mathrm{~W} / \mathrm{m}^{2}$ over the simulation time span.

Figure 14 shows that the input current after the fault suddenly jumps to the short-circuit current level. This ultimately increases the losses within the PV 

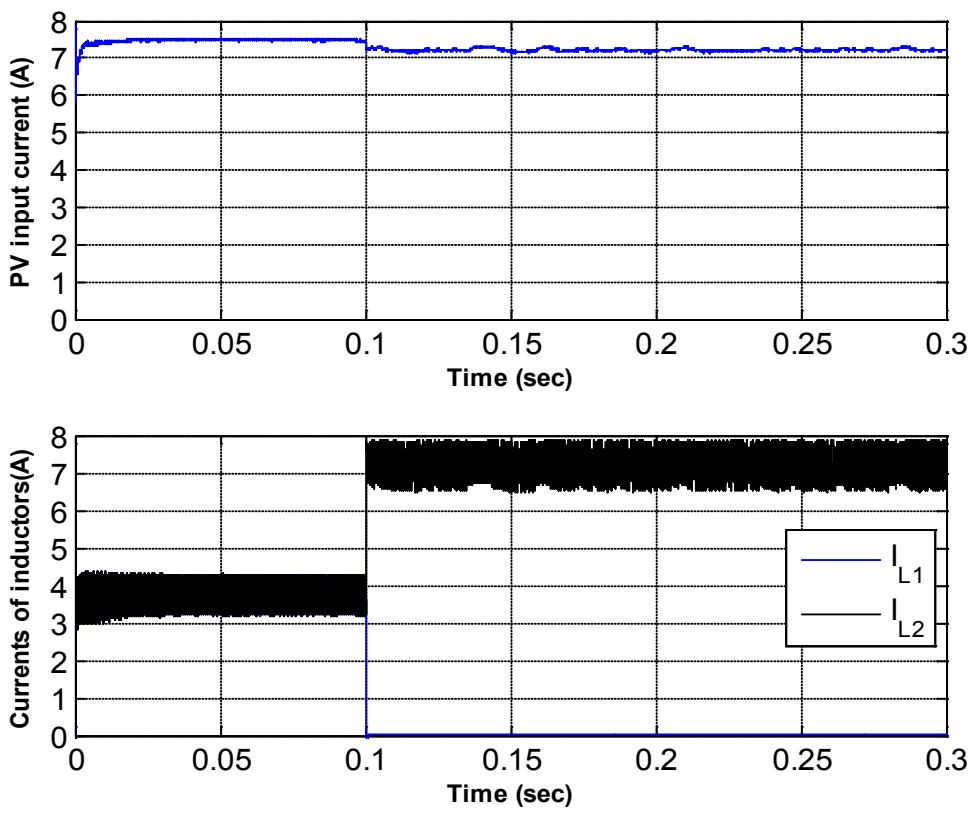

Figure 12. PV input current (Top graph), inductors' currents (bottom graph) for open-circuit switch fault at $100 \mathrm{msec}$.
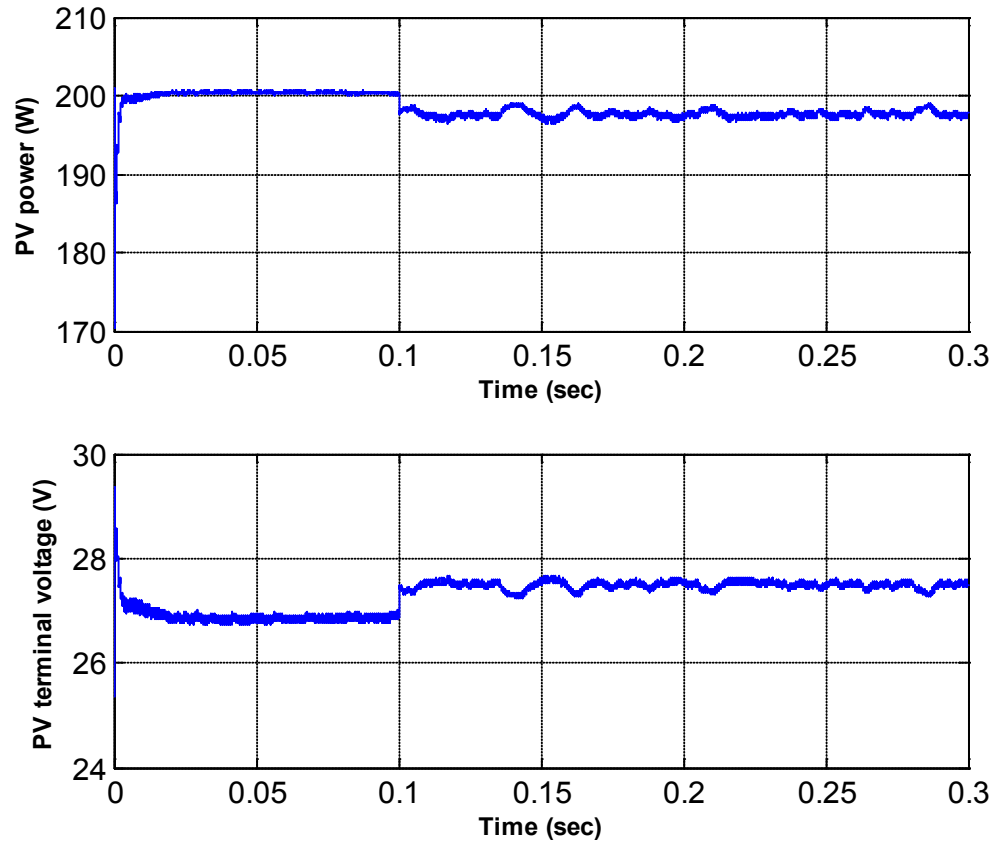

Figure 13. PV output power (Top graph), PV terminal voltage (bottom graph) for open-circuit switch fault at $100 \mathrm{msec}$.

generator. The DC-link voltage decreases to zero after the fault. The effect of the energy stored in the output capacitor is clear in Figure 14.

The proposed remedy is interfaced the interleaved boost converter to the PV generator via a switch. This switch would be continuously on during normal operation. However, it disconnects the circuit if the PV input current equals to the short-circuit current value. 

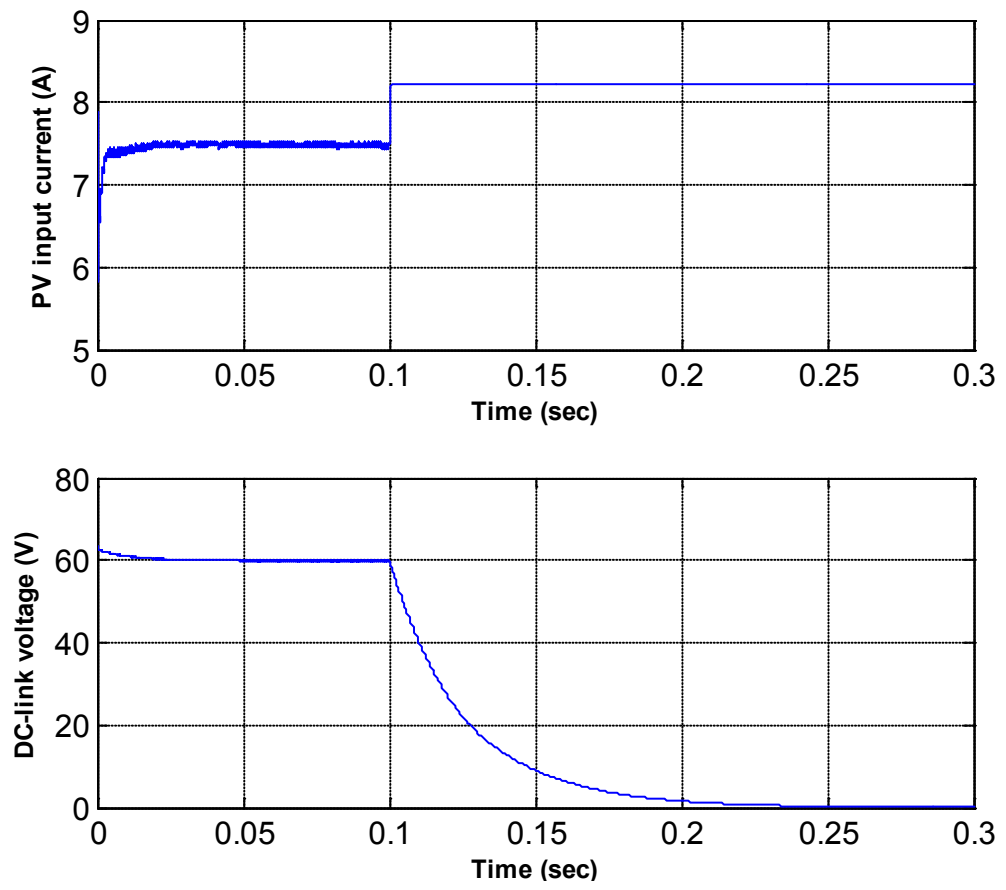

Figure 14. PV input current (Top graph), DC-link voltage (bottom graph) for short-circuit switch fault at $100 \mathrm{msec}$.

\subsection{Scenario\#3 a Diode Open-Circuit Fault}

This scenario investigates the open-circuit diode fault that develops in a converter cell. This scenario is illustrated in Figure 15 and Figure 16 where the PV module input current, inductors' currents, PV output power and voltage are drawn. Again, in this scenario, the solar irradiance is assumed constant at 1000 $\mathrm{W} / \mathrm{m}^{2}$ over the simulation time span.

Figure 15 shows the input current of PV generator and the currents in the inductors of the interleaved cells. It is clear that the proposed modulation strategy reduces the ripple, Figure 15 . The current in the inductor of the faulty cell becomes discontinuous, while the other cell carries the full load current.

The proposed remedy strategy is permantely to open the switch of the defected cell. This could be accomplished via continuous sensing of the inductors' currents.

Figure 16 shows that fault scenario results in around 20\% drop in the output power of the PV generator. The PV generator terminal voltage increases after the fault. This is due to departure of the operating point from MPP.

\section{Conclusions}

Efficient interleaved boost converter is proposed to interface a PV module into common DC-link. The article also identifies the condition for zero ripple in the interleaved boost converter input current. The limitations of the interleaved boost chopper are highlighted. An innovative implementation of the control circuit of interleaved boost converter is advised such that the two switches have 

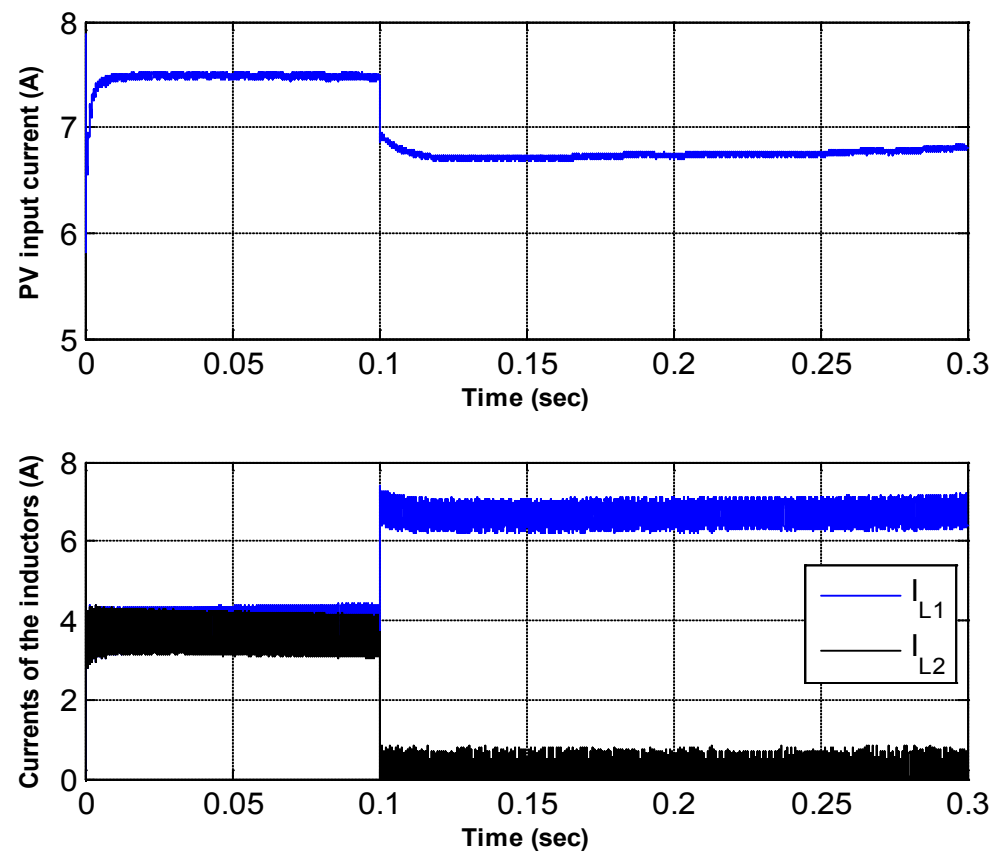

Figure 15. PV input current (Top graph), inductors' currents (bottom graph) for open-circuit diode fault at $100 \mathrm{msec}$.
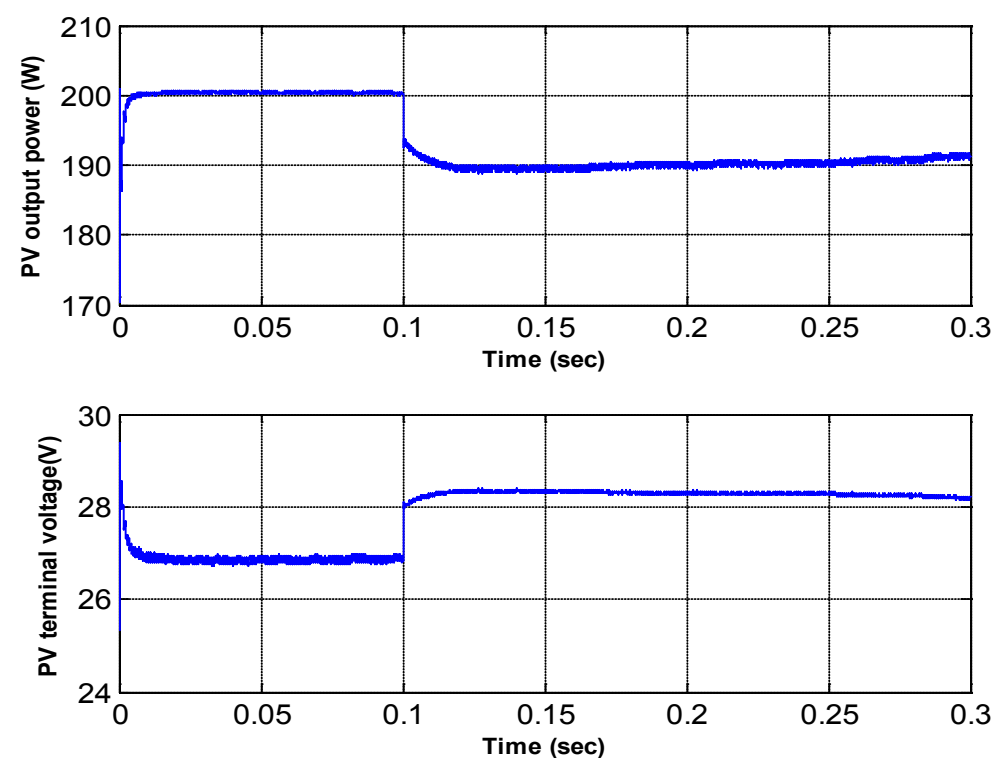

Figure 16. PV output power (Top graph), PV terminal voltage (bottom graph) for open-circuit diode fault at $100 \mathrm{msec}$.

equal value of the duty cycle.

The proposed control method of the interleaved boost converter enjoys the simplicity and flexibility [5] [6] [7] [8]. This method is not complicated as the reported control methods [5] [6] [7] [8]. Moreover, it allows almost instantaneous tracking for solar irradiance.

In general, the following conclusions could be extracted:

1) The interleaved boost converter has a maximum limit on the output vol- 
tage, as the output voltage is restricted to twice the input voltage. This limitation is not there in the basic boost cell.

2) The interleaved boost chopper could have ripple free input current, if the duty cycles of the two switches are equal and they are equal to $50 \%$.

An innovative implementation of switching strategy is advised to ensure equal value of duty cycles under varying levels of solar irradiance and temperature.

\section{References}

[1] Pranahita, B., Kumar, A and Babu, A. (2014) A Study on Modelling and Simulation of Photovoltaic Cells. International Journal of Research in Engineering and Technology, 10, 250-262.

[2] Keyser, D. and Bonilla, J. (2008) Model Predictive and Sliding Mode Control of a Boost Converter. IEEE Transaction on Power Electronics, 3, 401-410.

[3] Forouzesh, M., Siwakoti, Y.P., Gorji, S.A., Blaabjerg, F. and Lehman, B. (2017) Step-Up DC-DC Converters: A Comprehensive Review of Voltage-Boosting Techniques, Topologies, and Applications. IEEE Transactions on Power Electronics, 32, 9143-9178. https://doi.org/10.1109/TPEL.2017.2652318

[4] de Paula, A.N., de Castro Pereira, D., de Paula, W.J. and Tofoli, F.L. (2014) An Extensive Review of Non-Isolated DC-DC Boost-Based Converters. 11 th IEEE/IAS International Conference on Industry Applications, Juiz de Fora, 7-10 December 2014, 1-8.

[5] Pathy, S., Sridhar, R., Hari, N., Dash, S.S. and Subramani, C. (2016) A Modified Module Integrated-Interleaved Boost Converter for Standalone Photovoltaic (PV) Application. 2016 IEEE International Conference on Renewable Energy Research and Applications (ICRERA), Birmingham, 20-23 November 2016, 989-994. https://doi.org/10.1109/ICRERA.2016.7884483

[6] Apablaza, D. and Munoz, J. (2016) Laboratory Implementation of a Boost Interleaved Converter for PV Applications. IEEE Latin America Transactions, 14, 2738-2743. https://doi.org/10.1109/TLA.2016.7555247

[7] Chou, T.H., Lin, W.C., Lee, Y.S. and Yu, L.C. (2014) An Interleaved High Gain Boost Converter for High Power PV System Applications. TENCON 2014-2014 IEEE Region 10 Conference, Bangkok, 22-25 October 2014, 1-7. https://doi.org/10.1109/TENCON.2014.7022322

[8] Babu, A.R. and Raghavendiran, T.A. (2014) Analysis of Non-Isolated Two Phase Interleaved High Voltage Gain Boost Converter for PV Application. 2014 International Conference on Control, Instrumentation, Communication and Computational Technologies (ICCICCT), Kanyakumari, 10-11 July 2014, 491-496. https://doi.org/10.1109/ICCICCT.2014.6993012

[9] Esram, T. and Chapman, P.L. (2007) Comparison of Photovoltaic Array Maximum Power Point Tracking Techniques. IEEE Transactions on Energy Conversion, 22, 439-449. https://doi.org/10.1109/TEC.2006.874230

[10] Gomathy, S., Saravanan, S. and Thangavel, S. (2012) Design and Implementation of Maximum Power Point Tracking (MPPT) Algorithm for a Standalone PV System. International Journal of Scientific and Engineering Research, 3, 547-454.

[11] Gupta, A.K. and Saxena, R. (2016) Review on Widely-Used MPPT Techniques for PV Applications. 2016 International Conference on Innovation and Challenges in Cyber Security (ICICCS-INBUSH), Noida, 3-5 February 2016, 270-273. https://doi.org/10.1109/ICICCS.2016.7542321 
[12] Kundu, S., Gupta, N. and Kumar, P. (2016) Review of Solar Photovoltaic Maximum Power Point Tracking Techniques. 7 th India International Conference on Power Electronics (IICPE), Patiala, 17-19 November 2016, 1-6. https://doi.org/10.1109/IICPE.2016.8079494

[13] Abdelkader, H.I., Hatata, A.Y. and Hasan, M.S. (2015) Developing Intelligent MPPT for PV Systems Based on ANN and P \& O Algorithms. International Journal of Scientific \& Engineering Research (IJSER), 6, 367-373.

[14] Hafez, A.A. (2015) Multi-Level Cascaded DC/DC Converters for PV Applications. Alexandria Engineering Journal (AE), 54, 1135-1146. https://doi.org/10.1016/j.aej.2015.09.004

[15] (2011) KC200GT High Efficiency Multi-Crystal Photovoltaic Module Datasheet Kyocera. http://www.kyocera.com.sg/products/solar/pdf/kc200gt.pdf

[16] Abdelkader, H.I., Hatata, A.Y., Alansary, A. and Abo-Elsoud, M.A. (2015) Modeling and Simulation of Hybrid Concentrated Photovoltaic/Thermal System. International Journal of Scientific \& Engineering Research, 6, No. 4.

[17] Hafez, A.A. (2016) Simple High Voltage-Gain DC/DC Boost Converter for Renewable Energy Sources Interfacing. The Eighteenth International Middle East Power Systems Conference 2016, MEPCON`16, Cairo, 27-29 December 2016, 58-66. https://doi.org/10.1109/MEPCON.2016.7836872

[18] Erickson, R.W. and Maksimovic, D. (2001) Fundamental of Power Electronics. 2nd Edition, Springer, Berlin. https://doi.org/10.1007/b100747

[19] Burns, R.S. (2001) Advanced Control Engineering. Butterworth-Heinemann, Oxford. 